\title{
Harder Soft Governance in European Climate and Energy Policy: Exploring a New Trend in Public Policy
}

\author{
Michèle Knodt, ${ }^{1}$ Jonas J. Schoenefeld ${ }^{2}$
}

\begin{abstract}
:
While various forms of soft governance have been long in the making, there is a growing introduction of new policy elements in order to 'harden' soft governance arrangements. These new forms of 'harder' soft governance (HSG) vary in the degree of hardness in different settings. This special issue aims to derive lessons for climate and energy policy on HSG by looking across other policy fields and institutions where such 'hardening' has emerged, including in climate policy monitoring, the EU Energy Union, the UNFCCC, the OECD, the Open Method of Coordination, the European Semester, and policy surveillance in transnational city networks. Bringing the contributions together, this introduction reviews soft governance approaches, including their hardening. It then develops a framework for diagnosing HSG, including indicators such as obligations, justification, precision, 'blaming and shaming' opportunities, the role of third party actors, bundling, enforcement by policy field coupling, and sanctions. The introduction then identifies driving factors of HSG, including the role of the EU Member States, a strong need for coordination, policy entrepreneurs and institutional opportunities. The lessons from this special issue provide a useful yardstick for the future development of climate and energy governance, and the use of HSG in other policy fields.
\end{abstract}

Keywords: harder soft governance, soft governance, policy monitoring, European Semester, OECD, climate governance, Energy Union

\footnotetext{
${ }^{1}$ knodt@pg.tu-darmstadt.de, Institute of Political Science, Technical University of Darmstadt, Darmstadt, Germany

2 jonas.schoenefeld@tu-darmstadt.de, Institute of Political Science, Technical University of Darmstadt, Darmstadt, Germany; Tyndall Centre for Climate Change Research, School of Environmental Sciences, University of East Anglia, Norwich, UK
} 


\section{Introduction}

While debates on soft governance have long been of interest to a large community of scholars and practitioners, a novel tendency to introduce new policy elements in order to 'harden' soft arrangements demands attention. Especially in the area of climate and energy governance, lacking or limited competences make it difficult for EU-level policy-makers to influence national energy mixes. In order to progress in this challenging policy environment, the EU increasingly turns to soft governance approaches with novel 'harder' elements (Ringel \& Knodt, 2018), or harder soft governance (HSG) for short (Knodt, 2019a; Schoenefeld \& Knodt, 2020; see also Goldthau \& Sitter, 2015). According to Kooiman (2003, p. 4), governing comprises 'the totality of interactions, in which public as well as private actors participate, aimed at solving societal problems or creating societal opportunities [...].' The governance concept has often been used to describe and sometimes prescribe more flexible, horizontal and inclusive forms of steering than hierarchical, state-based command-and-control regulation (for the broader debates on governance, see Levi-Faur, 2012; Pierre, 2000). HSG presents a significant development from extant conceptualisations of soft governance, which have come into use in recent decades (Kohler-Koch \& Rittberger, 2006). This special issue starts from the premise that developments towards HSG have emerged in various different policy fields and organisations in parallel, but have not yet been brought together systematically, both in terms of their characteristics and their origins. Addressing this gap matters, lest scholars may miss significant ongoing governance developments. Drawing on experiences from various corners, the emerging findings from this special issue hold potential to derive lessons from earlier experiences. The recent HSG developments in the field of climate and energy policy make it a case in point for exploring the extent to which such lessons may be applied and how.

Because HSG has only recently been legislated in the area of climate and energy and has not yet been fully implemented, it is too soon to analyse its effectiveness. But the emergence of harder elements is in itself remarkable, because it reflects a broader trend towards HSG in various policy areas at the EU, as well as on the global level. Critical sites of extant soft governance with potentially harder elements that this special issue analyses include the Open Method of Coordination (OMC - see Borrás \& Jacobsson, 2004; De la Porte \& Nanz, 2004; Tholoniat, 2010), the European Semester (Van Der Veer, Reinout A \& Haverland, 2018; Verdun \& Zeitlin, 2018; Zeitlin \& Vanhercke, 2018), the United Nations Framework Convention on Climate Change (UNFCCC) (e.g., Oberthür \& Kelly, 2008; Oberthür, 2016) 
including associated monitoring processes in the EU (Schoenefeld, Hildén, \& Jordan, 2018; Schoenefeld, Schulze, Hildén, \& Jordan, 2019), and OECD processes (Aldy, 2014; see Aldy, 2018). This special issue also incorporates transnational city networks and their experience with harder soft governance and learning processes.

This introduction to the special issue proceeds as follows: the second section presents the state of the art of research on soft governance, which is the starting point for HSG. The third section discusses efforts to bridge soft and hard governance, and the fourth section elaborates a new framework in order to detect and analyse harder elements in soft governance, with a view to those identified in the context of this special issue. Section 5 works towards identifying a range of causal factors that may explain the emergence of harder elements. Finally, Section 6 presents the contributions to this special issue, while Section 7 concludes with key lessons for climate and energy policy in the EU that emerge from the contributions and presents opportunities for further research and analysis.

\section{Soft governance as a non-hierarchical steering mechanism}

New modes of governance (NMG) have been debated in the academic literature since the 1990s. The roots of this debate date back to the late 1960s and the 1970s, a time when the shortcomings of hierarchical steering and the growing importance of negotiations with organised societal interests became clearer (Citi \& Rhodes, 2006; Lange, Driessen, Sauer, Bornemann, \& Burger, 2013). Government decisions and corresponding enforcement of state policies based on hierarchical authority only permitted a narrowing scope of action, especially with rising societal resistance in some quarters. As a consequence, the possibilities of nonhierarchical steering instruments and mechanisms have especially been discussed at the international and European level (Czempiel \& Rosenau, 1992; Rhodes, 1996; Rhodes, 2007), but also in relation to hierarchical steering within states (e.g., Ellwein \& Hesse, 1994). Within this debate the shortcomings of the conventional use of 'governing' as the actions of states became obvious. The debate introduced the idea of governance (see above), which aims to conceptualise the interactions between various, mutually interdependent actors. These interactive arrangements build on 'horizontal forms of interaction between actors who have conflicting objectives, but who are sufficiently independent of each other so that neither can impose a solution on the other and yet sufficiently interdependent so that both would lose if no solution were found' (Schmitter, 2002, 53). Such liberal governance generates possibilities for 'solving societal problems or creating societal opportunities' (Kooiman, 2002, 73). 
It follows that NMGs are understood as the diametrical opposite to hierarchical steering. They rely on networks of actors which use coordination processes based on deliberation as a steering mechanism (Rhodes, 1996). NMGs appeared at a time when European integration advanced considerably. The Single European Market was completed in the 1990s and the Maastricht Treaty built a foundation for deeper integration. But not all viewed an ever more integrated Union as unequivocally positive. Especially the free movement of goods, services, and financial capital within the Single Market generated concerns about the negative effects of such integration on European citizens. But Member States were extremely reluctant to harmonise their social policies, especially because national social policies had emerged from strongly diverging traditions and goals. As a consequence, mounting pressure to address the negative consequences of the Single Market generated a preference for horizontal and voluntary mechanisms of policy coordination in order to achieve European solutions with Member State support (Scharpf, 2002).

One of the first significant attempts to implement voluntary policy coordination in the social policy field at EU level in the 1990s was the European Employment Strategy (EES). Soft governance mechanisms such as benchmarking, iterative reporting and country specific recommendations were implemented in the EES at the time (de la Porte \& Stiller, 2020). This experience was formalized and institutionalised in the creation of the OMC in 2000 (Tholoniat, 2010). The OMC reflects attempts to replace the missing transfer of competences to the European level with softer steering mechanisms in a systematic and formal way (Blomqvist, 2016, p. 272). It implies that Member State governments partially delegate communication and coordination tasks - rather than competences - to the European level (Knodt \& Ringel, 2018; Wallace, 2001, p. 592). Thus, the OMC can be characterized as a soft intergovernmental policy coordination instrument (Wallace, 2001, p. 592).

Different variations of the OMC have been used in various policy fields, including the European employment strategy (Zeitlin, Pochet, \& Magnusson, 2005), the stability and growth pact (Hodson, 2004), immigration policy (Caviedes, 2004), social policy (Atkinson, Marlier, \& Nolan, 2004), innovation policy (Kaiser \& Prange, 2004), and environmental policy (Twena, 2012). Related softer steering and new governance modes have also been detected in the area of climate change adaptation (Bauer, Feichtinger, \& Steurer, 2012). More specific 'assessment practices' based around evaluation and review (Meadowcroft \& Steurer, 2013; Stephenson, Schoenefeld, \& Leeuw, 2019), including the role of environmental monitoring and its consequences (Eshuis \& Van Woerkum, 2003; Jalbert \& Kinchy, 2016; 
Schoenefeld et al., 2018; Schoenefeld \& Rayner, 2019; Schoenefeld et al., 2019; Schoenefeld \& Jordan, 2019), have also been discussed, thus connecting with debates on the OMC. Taken together, the 1990s and the 2000s have been two decades of dynamic development of soft governance mechanisms.

\section{Advancing the debate - bridging the hard and soft governance divide}

At the international and at the European level, two scholarly communities have especially been debating these different types of governance, namely International Relations and the public policy analysis community. Scholars of international law have dominated the discussion within International Relations by mainly focusing on 'legalisation' and 'delegalisation' as a way of describing legislative change and especially the appearance of softer law (Abbott, Keohane, Moravcsik, Slaughter, \& Snidal, 2000; Saurugger \& Terpan, 2020; Terpan, 2015). The principal terminology used in this literature is 'hard' and 'soft law' (Peters \& Pagotto, 2006). This debate does not characterize hard law according to hierarchical steering competences as it is the case in the EU as well as at the national level. Instead it focuses on different design aspects of international law. Three key dimensions have been identified over time in order to distinguish between hard and soft law: obligation, precision and delegation. First, obligation describes whether or not a norm is legally binding; second, precision indicates how clear a rule is while, third, delegation refers to the extent to which implementation of the norm has been assigned to other actors (Abbott \& Snidal, 2000). Thus, hard law in international relations is characterised by a high degree of delegation to third parties such as international organisations or their subsidiaries. Such delegation may include the right to enforce compliance as well as a high level of obligations and precise description of obligations with little discretion. By contrast, soft law in international relations relies on direct political negotiation and diplomacy in the formulation and implementation of state agreements. It exerts a lower level and precision of obligations coupled with a higher level of discretion (Blomqvist, 2016, p. 268).

Movements between soft and hard law are possible. As Abbott et al. (2000) explain:

Over time, even nonbinding declarations can shape the practices of states and other actors and their expectations of appropriate conduct, leading to the emergence of customary law or the adoption of harder agreements. (p. 412)

Movement along the 'identifiable continuum from hard law through varied forms of soft law' (Abbott et al., 2000, p. 418) is therefore a theoretical possibility. What is missing is an 
exploration of the causal factors that may drive such processes. Furthermore, the debate of hard and soft law is only partially useful for the conceptualisation and analysis of harder soft governance in this special issue because it understands 'hard governance' as working solely through law and hierarchy.

By contrast, the public policy community has discussed the use of hard or soft policy tools and instruments in a dichotomy of standard legislation on the one side and soft governing tools on the other (Jordan, Wurzel, \& Zito, 2005). Blomqvist distinguishes between hard and soft policy tools along the following lines: hard tools such as legislation are more authoritative in character, representing hierarchical or 'top-down' power structures, whilst soft governing instruments are understood to be more deliberative or consensual, displaying a 'bottom-up steering logic' (2016, p. 269). While governance actors can delegate the implementation of hard legislation to courts, which can in turn apply sanctions in order to enforce compliance, soft tools cannot result in delegation of enforcement to third parties, given the lack of a legal basis. Hard policy tools are therefore perceived as more precise and fixed in their content while soft tools remain more vague and flexible (Blomqvist, 2016, p. 269; Jordan et al., 2005). But the dichotomy of hard and soft policy tools proved ultimately unhelpful in grasping differences in tools and nuances of European governance. For example, directives in European law are often imprecise and allow room for manoeuvre for the Member States (while they may be classified as hard law). At the same time some purported recommendations may lead to sanctions across different policy areas. Thus, it seems that the boundaries between hard and soft are already blurred. Therefore, scholars have suggested to treat hardness and softness of governance as a scale rather than a dichotomy (Abbott \& Snidal, 2000; Falkner, Treib, Hartlapp, \& Leiber, 2005; Trubek \& Trubek, 2005; Trubek \& Trubek, 2007).

Scholars have also developed concepts such as policy mixes to characterize the combination of different governance tools (Capano \& Howlett, 2020; Howlett \& Rayner, 2007). These are attempts to characterise what has been perceived as 'the continuous blurring between hard and soft, in which imposition and direct decision-making softens increasingly, while soft modes of governance, such as persuasion, naming and shaming, incentives and so on, become harder [...]' (Graziano \& Halpern, 2016, p. 5). In a similar vein, Schäfer (2006, p. 84) has highlighted that in the context of the (ostensibly soft) OMC 'the Commission ... has continually tried to harden the procedures through monitoring, quantitative indicators, and naming and shaming'. 
Building on these earlier contributions, we contend that these hardening processes have now advanced enough to be conceptualised as a distinct, new form of governance, namely harder soft governance (HSG). HSG is a dynamic approach to governance, which moves flexibly between softer and harder forms. It assesses variable degrees of hardness or softness at any one point in time. However, once rule-making becomes entirely legislation-based with clear targets and a clear enforcement mechanism, it would no longer be appropriate to call such an arrangement HSG. HSG is an essentially multilevel form of governance, which quintessentially rests on a soft governance foundation that has over time been supplemented with harder elements. The analytical approach is different from those who have attempted to introduce hybrid forms of soft/hard governance (Slominski, 2008; Trubek, Cottrell, \& Nance, 2005; Trubek \& Trubek, 2005), because it conceptualises a potentially infinite continuum between soft and hard governance, with varying levels of hardness in particular cases (drawing on Abbott et al., 2000; Abbott \& Snidal, 2000). The HSG approach goes beyond earlier conceptualisations in international law, which focused on aspects of the legal text, and also includes other elements typically missed by legal scholars, such as efforts at transparency (which may enable public naming and shaming) or the role of policy entrepreneurs. The hardening of HSG happens in the context of at least two actors and involving at least two different governance levels. The degree of hardness of soft governance therefore varies. The next section proposes a new framework in order to diagnose emerging elements of HSG and assess their hardness.

\section{Diagnosing 'harder' elements in soft governance arrangements}

The observed tendency towards HSG generates questions about the ways that have been found to 'harden' otherwise 'soft' governance arrangements. In order to assess the degree of hardness or softness of soft governance this contribution draws on the leading work on HSG in the context of energy governance in the EU (Knodt, 2018; Knodt \& Ringel, 2018; Knodt, 2019a; Knodt, 2019b; Ringel \& Knodt, 2018; Schoenefeld \& Knodt, 2020), in order to propose a new analytical framework to enable the contributions in this special issue to diagnose HSG. This framework contains the following hardening elements:

- Obligation: Drawing on Abbott, Keohane, Moravcsik, Slaughter and Snidal (2000), obligation may be understood as the extent to which 'states or other actors are bound by a rule or commitment' (p. 401). Departing from its earlier definition in international 
relations (see Abbott \& Snidal, 2000), we argue that the hardness of an obligation is a function of its formulation (or wording) within an agreement or a recommendation. For example, states would have to adhere to a 'harder' recommendation (e.g., issued by a third party with delegated authority) with 'utmost account' whereas a softer formulation would ask for 'due account' or 'account' (see Knodt, Ringel, \& Müller, 2020).

- Justification: A related concept to obligation is that of justification. The more states have to explain in detail why and how they do (not) react to a recommendation, the harder the governance becomes. By the same token, an absence of such a justification obligation would be judged as being 'softer' soft governance.

- Precision: The hard and soft law literature also proposes the level of precision as an additional way to gauge the level of hardness. The clearer the target, the harder the governance (Terpan, 2015, p. 73; see also Abbott et al., 2000). For example, precise shares of emissions reductions (expressed in \%) in the area of climate policy are considered harder than a policy that simply states that a country should contribute to emissions reductions.

- Blaming and shaming opportunities: The ability to blame and shame actors for their behaviour is key for soft governance (Trubek \& Trubek, 2005). The emergence of this element is a function of how much public debate is possible. In other words, are there platforms and places where the related debate can happen? The emergence of HSG implies a greater availability of platforms for 'blaming and shaming', both in public and among peers (Schäfer, 2006). Doing so hardens standard monitoring and reporting, which generates the opportunity for more publicity than normally enabled by 'soft' governance arrangements.

- Role of third-party actors at international/European level: A strong political role for third-party actors (including private actors) at international/European level is an indicator for 'harder' soft governance (see Van Der Veer, Reinout A \& Haverland, 2018) as the actor could be equipped with enforcement instruments such as the right to issue legal acts (tertiary law) to exert pressure. Truly 'soft' law would not conceptualise such a political role for a third party.

- Bundling within a policy field. Streamlining different policy elements within a single policy field (such as climate or energy policy) could lead to significant hardening effects. Doing so may increase policy cohesion by removing inconsistencies, 
generating synergies and strengthening the visibility and prominence of the policy field. Bundling may emerge through a new, overarching framework that combines previously disparate or disconnected policy elements (for a related discussion on policy mixes, see Howlett \& Rayner, 2007).

- Enforcement by coupling with other policy field(s): Another way to enforcement is to couple a softer governance mechanism with another policy field where sanctions are possible (for example through financial instruments). HSG would emerge through this kind of coupling, while its absence would indicate 'softer' governance.

- Sanctions: Direct sanctions are by definition limited in soft governance arrangements. However, actors may agree to put in place harder elements, such as financial fines. More explicit direct links with possible sanctions increase the hardness of soft governance. If there is no such possibility, we would speak of 'softer' soft governance. The contributions of this special issue were guided by this framework in order to analyse the soft governance mechanisms in their respective policy field, and then identifying the 'harder' soft governance elements and the overall degree of hardness. As most of the cases analysed here exhibit significant HSG, the aim is in asking what lessons could be derived from this process for the emerging climate change and energy governance.

\section{The origins of harder soft governance (HSG)}

\subsection{Soft governance as a starting point}

We start from the assumption that HSG emerges from softer governance approaches, which are gradually hardened by the introduction of additional elements over time - an assumption that the special issue contributions confirm (see below). Therefore, understanding HSG necessitates tracing the emergence of soft governance, and its dynamics. Numerous authors have detailed a range of functional drivers which may motivate actors to engage in soft governance. For example, Schäfer (2006, p. 71-72) argues that soft governance has proven more palatable in highly conflictual policy settings, as it has 'enabled [national governments] to reach an agreement without having to fear its consequences.' Soft governance frequently offers a 'procedural solution' that allows national governments flexibility because they do not have to agree on 'substance' (Schäfer, 2006, p. 83; see also Tholoniat, 2010). According to Schäfer (2006), it therefore 'minimizes sovereignty losses' (p. 83), 'helps overcome political resistance' (p. 83), allows blame shifting to the EU (p. 84), 'offers symbolic politics' (p. 84) 
suggesting determination and 'avoids a loss of control' (p. 84).

In a similar vein, legal scholars have argued that 'softer legalization is often easier to achieve than hard legalization' (Abbott \& Snidal, 2000, p. 423). Soft law may entail lower contracting costs (while still enjoying some of the benefits of hard law), lower 'sovereignty costs', i.e. the costs of losing control; greater ability to deal with uncertain issues because it allows some level of continued flexibility; and greater ability to foster political compromise than hard law (Abbott \& Snidal, 2000, p. 434-450). It has also been argued that softer governance may be more participatory, thus generating forms of self-governance that may also facilitate greater buy-in from participating actors (Graziano \& Halpern, 2016). Especially in the EU context, soft law has been viewed as a way to address growing implementation problems of hard law in the 1990s (Terpan, 2015, p. 90).

In addition to such functional drivers, certain pre-conditions may also facilitate the emergence of soft governance: Blomqvist (2016, p. 274) argues that 'generally speaking, the use of soft governing tools appears to be more likely in countries where local governments enjoy a high degree of autonomy, the executive tends to delegate significant powers to administrative agencies and legal traditions are weak'. Certain political system characteristics may thus make some places more prone to soft governance than others.

While the potential advantages of soft governance have been touted in the aforementioned literatures, especially concrete experiences with soft governance have started to raise some doubts about its ability to generate the desired effects (see Kohler-Koch \& Rittberger, 2006). Since there is certainly no guarantee that 'hard law' will be effectively implemented at all times and there are numerous reasons to comply with soft law, ranging from peer pressure to knowledge diffusion or blaming and shaming (Blomqvist, 2016), there is no guarantee that governance, whether soft or hard, will consistently produce the desired effects.

\subsection{Driving factors of HSG}

If soft governance does not generate the hoped-for effects, the resulting dissatisfaction can drive change towards HSG (Schoenefeld \& Jordan, 2020). Pressure emanating from the issue at stake - such as climate and energy policy in our case - can further exacerbate a sense of dissatisfaction and build a perceived urgency for change. HSG emerges from an attempt to address such dissatisfaction with governance results in an environment where traditional hard governance through legislation is out of reach, but where traditional mechanisms of soft 
governance are perceived to be too weak to achieve the desired goals.

The earlier literature discussed above has so far been weaker on conceptualising and empirically unpacking the driving forces behind HSG, or in other words the factors that may lead to the emergence of HSG. Given the lack of knowledge in this area, we chose an inductive approach: Having asked the authors in this special issue to provide some explanations for the emergence of HSG, we now use their insights in order to build a broader framework. Through this process, we have identified two broad sets of factors contributing to HSG: First, there are broader enabling conditions that increase the likelihood of soft governance with harder elements to emerge. The second set of factors refers to actors with concrete agendas and the ability to take advantage of such enabling conditions and put in place HSG.

\subsubsection{Enabling conditions of HSG}

The first enabling condition or contextual factor conducive of HSG relates to a strong need for coordination with limited possibilities for hard governance on legislation. In our focus area of climate and energy policy, scientific evidence on present and future climate change impacts suggests a great urgency of action. This urgency has generated considerable political pressure to act, especially in the context of implementing the Paris Agreement and achieving the European targets.

If such a need for coordination is met by a will of the Member States to act, another key problem arises. The limited possibilities for agreeing on hard legislation, given widely divergent priorities, make soft governance particularly attractive to move forward. Harder elements are then added in the process and potentially by skilled entrepreneurial activities of single or multiple institutions and/or in order to increase the effectiveness of the governance approach. This is usually done in response to a perceived underperformance of purely soft governance (see Schoenefeld \& Jordan, 2020).

A third enabling factor then concerns the presence and nature of institutional and organisational opportunity structures for HSG to arise (see McAdam, 1996). In addition to the above factors, the emergence of HSG depends on the exploitation of opportunities of implementation. For example, actors may capitalise on previous and successful instances of HSG in other areas, or they may link their endeavours to broader governance trends. More concretely, the probability for HSG rises with promising opportunities: Are there ways in 
which naming and shaming can be conducted, as is the case with organisations such as the OECD (Lehtonen, 2020) or the European Environment Agency (Schoenefeld \& Jordan, 2020)? To what extent are there opportunities for bundling within the same field or policy field coupling, generating for example sanctioning potential as had been suggested in the case of the emerging Energy Union (Knodt et al., 2020)? Such institutional and organisational factors play a key role in laying fertile soil on which HSG may flourish.

\subsubsection{Actors}

The exploitation of the aforementioned enabling factors is unlikely to happen unless there are actors who are willing and able to put HSG in place. In other words, policy entrepreneurs may play a key role (see Schäfer, 2006). The role of policy entrepreneurs (see Mintrom \& Norman, 2009) is crucial because functioning soft governance requires good will of the participants. Policy entrepreneurs - who may be public or private actors - may entice Member States to agree on HSG and therefore ensure some adherence to commonly agreed policy goals by varying the degree of hardness during negotiation processes. For example, the European Commission became a key entrepreneur in inserting harder elements into the Energy Union governance proposal, in particular by inserting a formula to calculate renewable contributions, as well as by bundling monitoring obligations and publishing them in the highly visible State of the Energy Union reports (Schoenefeld \& Knodt, 2020; Knodt et al., 2020; Schoenefeld \& Jordan, 2020; see also Eckhard \& Jankauskas, 2019). Taken together, entrepreneurial activities towards HSG have proven to be a crucial factor in the papers in this special issue.

\section{The contributions to the special issue}

In light of our new framework of HSG and its driving factors, the contributors to this special issue explored a range of policy areas and institutions where approaches to hardening soft governance have been applied. These include climate policy monitoring, the EU Energy Union, the UNFCCC, the OECD, the Open Method of Coordination, the European Semester, and policy surveillance in transnational city networks. This section summarises each contribution in turn. In each case, we asked the authors to assess the level of HSG, explore its origins and derive lessons for the emerging climate and energy governance in the EU.

Jonas Schoenefeld and Andrew Jordan (2020) turn to HSG in the EU's efforts to monitor 
climate policies and measures through a Monitoring Mechanism, as well as the efforts to harden monitoring. They find that over the decades-long history of the mechanism, efforts at hardening have particularly emerged in the last ten years, related to the changing legal form of monitoring, more detailed legal prescriptions of reporting content, more publicity and thus opportunities for naming and shaming, linking with existing EU reporting cycles, and incorporation in other policy planning processes, such as in the context of the Energy Union. They find that these effects have mainly been driven by changing actor constellations, with the European Commission, the Member States and the European Environment Agency playing particularly prominent roles as policy entrepreneurs. While demonstrating the dynamic nature of policy monitoring over time certainly matters for future developments, the authors also caution to pay close attention to the efficacy of HSG in the longer term.

Michèle Knodt, Marc Ringel and Rainer Müller (2020) focus on the emerging EU Energy Union, which was the original motivation to bring together this special issue, and generate lessons from other policy fields - but already in itself a key site of emerging HSG (Knodt, 2019a). Focusing on the Governance Regulation of December 2018, they start from the conceptual assumption that there are varieties of soft governance which vary as a function of hardness. They diagnose that HSG in EU energy governance emerged precisely because the EU Member States were unwilling to transfer significant decision-making power to the EU level as they remain deeply divided over the ends of EU climate and energy policy. The authors advance to demonstrate the features of harder energy governance in the EU, which has drawn strength from various corners. Particularly the Commission has emerged as a key policy entrepreneur in driving this development, not least motivated by its own political selfinterest.

Turning to the international level, Sebastian Oberthuer and Elisabeth Groen (2020) analyse processes of softening and hardening in international climate governance under the UNFCCC over time, all the way from the Kyoto Protocol to the Paris Agreement. Their work - based on an assessment of 'stringency' developed in the debates leading to this special issue - reveals that hardening and softening may be differentiated for different actors, even if the underlying governance approach (such as the Paris Agreement) is the same. The approach constitutes a softening for actors such as the EU, but a hardening for many developing countries, which had previously not been assigned a strong role in reducing global greenhouse gas emissions. 
The paper demonstrates that these developments emerged because of interest-driven political considerations of the most powerful actors, rather than out of functional or rational policybased concerns. But there was also a desire of learning from the past. While international climate governance has become more inclusive, concerns remain about the necessary levels of ambition, as well as implementation. In sum, the authors conclude that the 'incremental hardening' may be 'too little, too late' in order to be commensurate with the challenge of containing climate change. So, while the authors caution against automatically assuming effectiveness of the HSG, they argue that the EU's institutional backdrop and its already 'harder' climate governance generates some cause for hope.

Markku Lehtonen (2020) focuses on the hardening of soft governance processes in the Organisation for Economic Co-operation and Development (OECD), starting from the observation that the OECD's potential strength lies in its ability to provide a forum for 'frank debates on hot topics'. Lehtonen assesses the OECD's environmental performance reviews, the economic surveys, as well as the International Energy Agency's energy policy reviews, as among the oldest and most developed examples of 'soft governance' at the international level. The article highlights the multiple trade-offs between different types of hardening, as well as between hardness and softness. Hardening is not an end in itself, and does not necessarily equate with greater impact. Drawing on the typology of 'hardening' outlined above, Lehtonen highlights the trade-offs between the more conventional types of hardening on the one hand (obligation; precision; justification; and blaming and shaming) and two more novel types of hardening on the other: 'bundling within a policy field' and 'enforcement by coupling with other policy fields.' The analysis draws attention to the limits of a dichotomous conceptualisation of hard vs. soft governance, and to the various governance design choices within the extensive grey area between the two extremes of 'hard' and 'soft.' Lehtonen concludes that the OECD peer reviews implicitly represent a form of 'advocacy evaluation' that crucially shapes the 'soft vs. hard' choices, and that hardening efforts by an organisation such as the OECD need to build on the 'soft' foundations of trust, socialisation and community-building.

Looking at the EU level, Caroline De la Porte and Sabina Stiller (2020) focus on the Open Method of Coordination (OMC) as a key source of lessons for the Energy Union. They explain that the $\mathrm{OMC}$, a structured and iterative form of policy coordination, first emerged in 
the late 1990s, and has been applied successfully to a range of policy areas, including employment, pensions and social inclusion policy. A 'hardening' in an OMC process includes, first, the setting of specific EU benchmarks and national targets, which are decided at the highest political level. Especially in the climate and energy sector, the presence of such benchmarks enables continuous focus on policies to meet EU benchmarks (in the shape of national targets), which constitutes hardening of soft governance. Secondly, the authors explain that the OMC effectively involves two-level political dialogue at the administrative level, thus exhibiting a feature that is central to HSG in terms of issue ownership. Third, the OMC allows policy entrepreneurs - at the EU and national levels - to put and maintain issues from OMCs on European and national agendas. De la Porte and Stiller conclude that these three hardening effects crucially depend on two factors: national institutional capabilities and available EU financial resources.

Pierre Bocquillon, Eleanor Brooks and Tomas Maltby (2020) in turn derive lessons for the Energy Union from the European Semester, and especially related developments in the health sector. The Semester is a six-month macro-economic policy planning and coordination process, which has expanded to address almost all policy areas. Combining the Experimentalist Governance Framework with HSG, the authors focus on the instruments, processes and actors involved in the Semester. Elements of hardening emerge as the nonobservance of recommendations by the Member States may lead to sanctions from the European level through the Stability \& Growth Pact. Others - also observable in energy include, for example, setting high thresholds for change in overturning EU-level decisions, coupling with other established policy fields and instruments, highly specific objectives and politicization of their implementation. They find that HSG in both the health and the energy sectors has emerged from a combination of incomplete competencies, debates over national sovereignty, as well as from skilful entrepreneurial interventions.

Fabrizio De Francesco, Lucas Leopold and Jale Tosun (2020) centre on HSG in the context of transnational city networks in climate and energy governance. They argue that, depending on these networks' funding sources and functional purposes, the arrangements for monitoring transnational efforts can be hardened through 'naming and shaming' as well as sanctioning mechanisms. The authors identify several dimensions - including for example the collection of quantitative vs. qualitative information, the engagement of peers or the transparency of the 
system - along which hardening may occur and can be distinguished from softer forms of transnational coordination, such as policy tracking that showcases cities' experiences with climate and energy actions. This culminates in the expectation that policy collaboration and monitoring systems organised by institutions that are independent from the networks' member cities tend to be 'harder' - and are more focused on accountability and learning in order to comply with common policy pledges and targets - than policy tracking systems put in place by cities themselves. Analysing the Covenant of Mayors for Climate \& Energy, as well as the Energy Cities network, De Francesco, Leopold and Tosun find that these expectations generally bear out in their comparative analysis. HSG is more likely to emerge in contexts with a stronger multi-level component built on international pledges and policy targets than in more bottom-up arrangements. Remarkably, hardening governance arrangements proved possible even in the absence of a clear legislative mandate to do so.

\section{Conclusion and next steps}

The contributions to this special issue demonstrate that efforts to introduce HSG are by no means isolated attempts, but rather reflect a broader trend to govern in conflictual policy environments. There are numerous opportunities for future research emerging from this special issue. One area of exploration comprises the efficacy of HSG in the context of the Energy Union. While it was too soon to assess its effects in this special issue, future scholars will be in a better position to collect empirical data and discuss the effectiveness of HSG in governing energy and climate change in the EU. This especially matters for elements such as 'naming and shaming', where it will be important to gauge whether the opportunities that this special issue has identified have been exploited.

Furthermore, we have so far not attempted to assess the relative weight of individual driving factors of HSG. For example, are some of the mechanisms more effective at hardening or softening than others? What combination of factors is most conducive to bringing about HSG? Building on the conceptual framework offered here, future scholars will be in a good position to provide such assessments and therefore dig deeper into the mechanics of HSG. The results of such research endeavours will be especially relevant for the emerging European Green Deal and the proposed European Climate Law which contain significant HSG provisions. 


\section{References}

Abbott, K. W., Keohane, R. O., Moravcsik, A., Slaughter, A., \& Snidal, D. (2000). The concept of legalization. International Organization, 54(3), 401-419.

Abbott, K. W., \& Snidal, D. (2000). Hard and soft law in international governance. International Organization, 54(3), 421-456.

Aldy, J. E. (2014). The crucial role of policy surveillance in international climate policy. Climatic Change, 126(3-4), 279-292.

Aldy, J. E. (2018). Policy surveillance: Its role in monitoring, reporting, evaluating and learning. In A. Jordan, D. Huitema, H. van Asselt \& J. Forster (Eds.), Governing climate change: Polycentricity in action? (pp. 210-227). Cambridge: Cambridge University Press.

Atkinson, A. B., Marlier, E., \& Nolan, B. (2004). Indicators and targets for social inclusion in the European Union. Journal of Common Market Studies, 42(1), 47-75.

Bauer, A., Feichtinger, J., \& Steurer, R. (2012). The governance of climate change adaptation in 10 OECD countries: Challenges and approaches. Journal of Environmental Policy \& Planning, 14(3), 279-304.

Blomqvist, P. (2016). Soft and hard governing tools. In C. Ansell, \& J. Torfing (Eds.), Handbook on theories of governance (pp. 267-278). Cheltenham: Edward Elgar Publishing.

Bocquillon, P., Brooks, E., \& Maltby, T. (2020). Speak softly and carry a big stick: Hardening soft governance in EU energy and health policies. Journal of Environmental Policy and Planning, doi: https://doi.org/10.1080/1523908X.2020.1792860

Borrás, S., \& Jacobsson, K. (2004). The open method of co-ordination and new governance patterns in the EU. Journal of European Public Policy, 11(2), 185-208.

Capano, G., \& Howlett, M. (2020). The knowns and unknowns of policy instrument analysis: Policy tools and the current research agenda on policy mixes. SAGE Open, 10(1), 2158244019900568 .

Caviedes, A. (2004). The open method of co-ordination in immigration policy: A tool for prying open fortress europe? Journal of European Public Policy, 11(2), 289-310.

Citi, M., \& Rhodes, M. (2006). New modes of governance in the european union: A critical survey and analysis. In K. E. Jørgensen, M. A. Pollack \& B. Rosamond (Eds.), Handbook of European Union politics (pp. 463-482). London; Thousand Oaks, Calif.: SAGE. 
Czempiel, E. O., \& Rosenau, J. (1992). Governance without government: Order and change in world politics.

De Francesco, F., Leopold, L., \& Tosun, J. (2020). Distinguishing policy surveillance from policy tracking: Transnational municipal networks in climate and energy governance. Journal of Environmental Policy and Planning, doi: https://doi.org/10.1080/1523908X.2020.1785280

De la Porte, C., \& Nanz, P. (2004). The OMC-a deliberative-democratic mode of governance? the cases of employment and pensions. Journal of European Public Policy, 11(2), 267-288.

de la Porte, C., \& Stiller, S. (2020). Lessons about the 'harder' elements of OMC governance for the EU energy union. Journal of Environmental Policy and Planning, doi: https://doi.org/10.1080/1523908X.2020.1785281

Eckhard, S., \& Jankauskas, V. (2019). International bureaucracies as strategic actors: How the better regulation reform strengthens the european commission. Politische Vierteljahresschrift, 60(4), 681-699. doi: https://doi.org/10.1007/s11615-019-00189-3

Ellwein, T., \& Hesse, J. J. (1994). Der überforderte Staat. Baden-Baden: Nomos.

Eshuis, J., \& Van Woerkum, C. (2003). Trust and monitoring in governance processes: Lessons from landscape management by farmers in a Dutch municipality. Journal of Environmental Policy \& Planning, 5(4), 379-396.

Falkner, G., Treib, O., Hartlapp, M., \& Leiber, S. (Eds.). (2005). Complying with Europe: EU harmonisation and soft law in the member states. Cambridge: Cambridge University Press.

Goldthau, A., \& Sitter, N. (2015). Soft power with a hard edge: EU policy tools and energy security. Review of International Political Economy, 22(5), 941-965.

Graziano, P. R., \& Halpern, C. (2016). EU governance in times of crisis: Inclusiveness and effectiveness beyond the 'hard' and 'soft' law divide. Comparative European Politics, 14(1), 1-19.

Hodson, D. (2004). Macroeconomic co-ordination in the Euro area: The scope and limits of the open method. Journal of European Public Policy, 11(2), 231-248.

Howlett, M., \& Rayner, J. (2007). Design principles for policy mixes: Cohesion and coherence in 'new governance arrangements'. Policy and Society, 26(4), 1-18. 
Jalbert, K., \& Kinchy, A. J. (2016). Sense and influence: Environmental monitoring tools and the power of citizen science. Journal of Environmental Policy \& Planning, 18(3), 379397.

Jordan, A., Wurzel, R. K., \& Zito, A. (2005). The rise of 'new' policy instruments in comparative perspective: Has governance eclipsed government? Political Studies, 53(3), 477-496.

Kaiser, R., \& Prange, H. (2004). Managing diversity in a system of multi-level governance: The open method of co-ordination in innovation policy. Journal of European Public Policy, 11(2), 249-266.

Knodt, M. (2018). EU energy policy. In H. Heinelt, \& S. Münch (Eds.), Handbook of european policies: Interpretive approaches to the EU (pp. 224-240). Cheltenham: Edward Elgar.

Knodt, M. (2019a). Multilevel coordination in EU energy policy: A new type of "harder" soft governance? In N. Behnke, J. Broschek \& J. Sonnicksen (Eds.), Configurations, dynamics and mechanisms of multilevel governance (pp. 173-191). Cham (Switzerland): Palgrave Macmillan/Springer Nature.

Knodt, M. (2019b). Steuerung der Energietransformation durch die EU. DMS-Der Moderne Staat-Zeitschrift für Public Policy, Recht und Management, 12(2), 367-381.

Knodt, M., \& Ringel, M. (2018). The European Commission as a policy shaper-harder soft governance in the Energy Union. In J. Ege, M. W. Bauer \& S. Becker (Eds.), The European Commission in turbulent times (pp. 181-206). Baden-Baden: Nomos.

Knodt, M., Ringel, M., \& Müller, R. (2020). 'Harder' soft governance in the European Energy Union. Journal of Environmental Policy and Planning, doi: https://doi.org/10.1080/1523908X.2020.1781604

Kohler-Koch, B., \& Rittberger, B. (2006). Review article: The 'governance turn' in EU studies. Journal of Common Market Studies, 44, 27-49.

Kooiman, J. (2003). Governing as governance. Thousand Oaks: Sage.

Lange, P., Driessen, P. P., Sauer, A., Bornemann, B., \& Burger, P. (2013). Governing towards sustainability — conceptualizing modes of governance. Journal of Environmental Policy \& Planning, 15(3), 403-425.

Lehtonen, M. (2020). Harder governance built on soft foundations: Experience from OECD peer reviews. Journal of Environmental Policy and Planning, doi: https://doi.org/10.1080/1523908X.2020.1793746 
Levi-Faur, D. (2012). Oxford handbook of governance. Oxford: Oxford University Press. McAdam, D. (1996). Conceptual origins, current problems, future directions. In D. McAdam, J. D. McCarthy \& M. N. Zald (Eds.), Comparative perspectives on social movements: Political opportunities, mobilizing structures, and cultural framings (pp. 23-40). Cambridge: Cambridge University Press.

Meadowcroft, J., \& Steurer, R. (2013). Assessment practices in the policy and politics cycles: A contribution to reflexive governance for sustainable development? Journal of Environmental Policy \& Planning, , 1-23.

Mintrom, M., \& Norman, P. (2009). Policy entrepreneurship and policy change. Policy Studies Journal, 37(4), 649-667.

Oberthür, S. (2016). Where to go from Paris? The European Union in climate geopolitics. Global Affairs, 2(2), 119-130.

Oberthür, S., \& Kelly, C. R. (2008). EU leadership in international climate policy: Achievements and challenges. The International Spectator, 43(3), 35-50.

Peters, A., \& Pagotto, I. (2006). Soft law as a new mode of governance: A legal perspective. NEWGOV: New Modes of Governance, doi: http://dx.doi.org/10.2139/ssrn.1668531

Pierre, J. (2000). Introduction: Understanding governance. In J. Pierre, Debating Governance: Authority, Steering, and Democracy, (pp.1-10). Oxford: Oxford University Press.

Rhodes, R. A. W. (1996). The new governance: Governing without government. Political Studies, 44(4), 652-667.

Rhodes, R. A. W. (2007). Understanding governance: Ten years on. Organization Studies, $28(8), 1243-1264$.

Ringel, M., \& Knodt, M. (2018). The governance of the European Energy Union: Efficiency, effectiveness and acceptance of the winter package 2016. Energy Policy, 112, 209220.

Saurugger, S., \& Terpan, F. (2020). Normative transformations in the European Union: On hardening and softening law. West European Politics, doi: https://doi.org/10.1080/01402382.2020.1762440

Schäfer, A. (2006). A new form of governance? comparing the open method of co-ordination to multilateral surveillance by the IMF and the OECD. Journal of European Public Policy, 13(1), 70-88.

Scharpf, F. W. (2002). The European social model. Journal of Common Market Studies, 40(4), 645-670. 
Schoenefeld, J. J., Hildén, M., \& Jordan, A. J. (2018). The challenges of monitoring national climate policy: Learning lessons from the EU. Climate Policy, 18(1), 118-128.

Schoenefeld, J. J., \& Jordan, A. J. (2019). Environmental policy evaluation in the EU: Between learning, accountability, and political opportunities? Environmental Politics, $28(2), 365-384$.

Schoenefeld, J. J., \& Jordan, A. J. (2020). Towards harder soft governance? Monitoring climate policy in the EU. Journal of Environmental Policy and Planning, doi: https://doi.org/10.1080/1523908X.2020.1792861

Schoenefeld, J. J., \& Knodt, M. (2020). Softening the surface but hardening the core? Governing renewable energy in the EU. West European Politics, doi: https://doi.org/10.1080/01402382.2020.1761732

Schoenefeld, J. J., \& Rayner, T. (2019). Monitoring energy policy. In M. Knodt, \& J. Kemmerzell (Eds.), Handbook of energy governance in Europe. Cham, Switzerland: Springer. doi: https://doi.org/10.1007/978-3-319-73526-9_43-1

Schoenefeld, J. J., Schulze, K., Hildén, M., \& Jordan, A. (2019). Policy monitoring in the EU: The impact of institutions, implementation and quality. Politische Vierteljahresschrift, 60(4), 719-741.

Slominski, P. (2008). Taking hybridity of hard and soft forms of governance seriously: Concept, choice and interaction of legal instruments in the EU. Paper presented at the ECPR Standing Group on the European Union Pan-European Conference, Riga, 2728.

Stephenson, P., Schoenefeld, J. J., \& Leeuw, F. L. (2019). The politicization of evaluation: Constructing and contesting EU policy performance. Politische Vierteljahresschrift, 60(4), 663-679.

Terpan, F. (2015). Soft law in the European Union - the changing nature of EU law. European Law Journal, 21(1), 68-96.

Tholoniat, L. (2010). The career of the open method of coordination: Lessons from a 'soft' EU instrument. West European Politics, 33(1), 93-117.

Trubek, D. M., Cottrell, M. P., \& Nance, M. (2005). 'Soft law,' 'hard law,' and European integration: Toward a theory of hybridity. University of Wisconsin Legal Studies Research Paper, No. 1002. Retrieved from https://papers.ssrn.com/sol3/papers.cfm?abstract_id=855447 
Trubek, D. M., \& Trubek, L. G. (2005). Hard and soft law in the construction of social Europe: The role of the open method of co-ordination. European Law Journal, 11(3), 343-364.

Trubek, D. M., \& Trubek, L. G. (2007). New governance and legal regulation: Complementarity. Rivalry, and Transformation, 13, 1-26.

Twena, M. (2012). Networked environmental governance in the European Union: Who participates and (how) do they learn? (Unpublished $\mathrm{PhD}$ ). University of East Anglia, Norwich. Retrieved from https://ueaeprints.uea.ac.uk/41973/

Van Der Veer, Reinout A, \& Haverland, M. (2018). Bread and butter or bread and circuses? Politicisation and the European Commission in the European Semester. European Union Politics, 19(3), 524-545.

Verdun, A., \& Zeitlin, J. (2018). Introduction: The European Semester as a new architecture of EU socioeconomic governance in theory and practice. Journal of European Public Policy, 25(2), 137-148.

Wallace, H. (2001). The changing politics of the EU: An overview. Journal of Common Market Studies, 39(4), 581-594.

Zeitlin, J., Pochet, P., \& Magnusson, L. (Eds.). (2005). The open method of coordination in action: The European employment and social inclusion strategies. Brussels: Peter Lang.

Zeitlin, J., \& Vanhercke, B. (2018). Socializing the European semester: EU social and economic policy co-ordination in crisis and beyond. Journal of European Public Policy, 25(2), 149-174. 